\title{
The hemolymph clottable proteins of tiger shrimp, Penaeus monodon, and related species
}

\author{
Maw-Sheng Yeh ${ }^{\text {a }}$, Yuh-Ling Chen ${ }^{\mathrm{b}}$, Inn-Ho Tsai ${ }^{\mathrm{a}, \mathrm{b}, *}$ \\ a Institute of Biochemical Sciences, National Taiwan University, Taipei, Taiwan, ROC \\ ${ }^{\mathrm{b}}$ Institute of Biological Chemistry, Academia Sinica, Taipei, Taiwan, ROC
}

Received 10 April 1998; received in revised form 29 June 1998; accepted 1 July 1998

\begin{abstract}
A clottable protein was purified from the hemolymph of tiger shrimp (Penaeus monodon) by sequential DEAE anion-exchange chromatography. The protein formed stable clots in the presence of $\mathrm{Ca}^{2+}$ and the transglutaminase in hemocyte lysate. It is thermostable at temperatures up to $66^{\circ} \mathrm{C}$. The molecular mass of the clottable protein was determined to be $380 \mathrm{kDa}$ by SDS-PAGE and MALDI-TOF mass spectrometry, and the protein exists as disulfide-linked homodimers and oligomers. The size and amino acid composition of the clottable protein are similar to those of several other shrimps, prawns, lobster and crayfish, and their N-terminal amino acid sequences are $60-80 \%$ identical. Monosaccharide analysis of the clottable protein revealed the presence of mannose, glucosamine or $N$-acetylglucosamine and possibly glucose in this glycoprotein of about $5 \%$ sugar content. Lipid in the protein upon electrophoresis was hardly detectable with the Oil Red O staining method. In immunodiffusion and immunoblotting analyses, the anti-clottable protein antibodies reacted with the clottable proteins from the penaeid shrimps but not with those from other crustaceans. (c) 1998 Elsevier Science Inc. All rights reserved.
\end{abstract}

Keywords: Clottable protein; Hemolymph coagulation; Purification; Mass spectrometry; Amino acid sequence; Monosaccharide analysis; Immunodiffusion; Shrimp

\section{Introduction}

Coagulation of the hemolymph is an essential defense mechanism of crustaceans which possess an open circulatory system. It prevents both the loss of body fluid and the entry of opportunistic pathogens. Three types of hemolymph coagulation in crustaceans have been described [29]. Type A coagulation (where a dense hemocyte network is sufficient to seal the wound) is

Abbreviations: HLS, hemocyte lysate supernatant; MALDI-TOF MS, matrix-associated laser desorption/ionization-time-of-flight mass spectrometry; SDS-PAGE, sodium dodecyl sulfate-polyacrylamide gel electrophoresis.

* Corresponding author. Institute of Biological Chemistry, P.O. Box 23-106, Taipei 10798, Taiwan, ROC. Tel: + 886223620261 , ext 2011; fax: + 8862 23635038; e-mail: bc201@gate.sinica.edu.tw seen in the crab Loxorhynchus grandis; type B (hemocyte aggregation is followed by plasma coagulation) occurs in the Maine lobster (Homarus americunus); and type $\mathrm{C}$ (involving the explosive cells or hyaline cells) is present in the spiny lobster and shrimps [17]. These three types are likely variations of a basic mechanism involving both hemocyte aggregation and coagulation of hemolymph proteins $[9,5]$. The major hemolymph protein involved in coagulation is designated herein as the clottable protein $[10,11,28]$. The clottable proteins from the spiny lobster (Panulirus interruptus) [11,12] and the crayfish (Pacifastacus leniusculus) [21] have been identified to be homodimeric lipoglycoproteins of about $400 \mathrm{kDa}$. The $\mathrm{N}$-terminal amino acid sequence of the lobster clottable protein is $30 \%$ identical to that of Caenorhabditis elegans vitellogenins but not similar to those of vertebrate fibrinogens [8]. A calcium-dependent 
transglutaminase in the decapod hemocytes (hyaline cells) plays an essential role in the coagulation processes $[12,23]$. In addition, the Factor XIIIa-like enzyme is known to catalyze the covalent cross-linking between subunits of the clottable protein [13,23]. The tiger shrimp, Penaeus monodon, used in this study is an economically important species cultured in Taiwan and southeastern Asia. We wish to understand its basic coagulation system. The shrimp has a high hyaline cell count (54\%) [6] and appears to perform type C coagulation. In this study we have purified and characterized the clottable protein from the shrimp and several related species. Biochemical and immunochemical comparisons between the clottable proteins of some decapod species in Taiwan are to be presented.

\section{Materials and methods}

\subsection{Hemolymph and hemocyte lysate}

The intermolt tiger shrimps of $20-25 \mathrm{~g}$ each were purchased from local markets and kept in aerated seawater. The hemolymph $(1 \mathrm{ml})$ was withdrawn from the ventral sinus located at the base of the first abdominal segment, using a $23 \mathrm{G}$ needle syringe containing 0.1 $\mathrm{ml}$ anticoagulant $(50 \mathrm{mM}$ EGTA, $18 \mathrm{mM}$ Tris- $\mathrm{HCl}$, $0.35 \mathrm{M} \mathrm{NaCl}, 13 \mathrm{mM} \mathrm{KCl}, 1.67 \mathrm{mM}$ D-glucose, $\mathrm{pH}$ 7.5) [4]. The hemocytes were immediately spun down at $300 \times g$ at $4^{\circ} \mathrm{C}$ for $10 \mathrm{~min}$, and the supernatant was pooled for preparing the clottable protein. The pellets were washed once with the anticoagulant, then hypotonically lysed in $100 \mu 1$ of $10 \mathrm{mM}$ Tris $-\mathrm{HCl}(\mathrm{pH} 7.5)$. The hemocyte lysate was centrifuged at $12000 \times g$ at $4^{\circ} \mathrm{C}$ for $30 \mathrm{~min}$ and the supernatant (HLS) was collected and used for experiments in the same day.

\subsection{Protein purification and clotting assay}

The tiger shrimp plasma (containing $2.4 \mathrm{~g}$ proteins in $30 \mathrm{ml}$ ) was dialyzed against $50 \mathrm{mM}$ Tris $-\mathrm{HCl}, 1 \mathrm{mM}$ EDTA, pH 8.0 (TE buffer) for $14 \mathrm{~h}$ at $4^{\circ} \mathrm{C}$. It was twice subjected to sequential chromatography at $4^{\circ} \mathrm{C}$ on a TSK DEAE-650 (S) column $(2.5 \times 9 \mathrm{~cm})$ pre-equilibrated with TE buffer alone or with $0.1 \mathrm{M} \mathrm{NaCl}$, and eluted with a step-wise gradient of $\mathrm{NaCl}$. Protein concentrations were determined by the Bradford method [2], using bovine serum albumin as a standard. For clotting assay, each fraction was dialyzed against 50 $\mathrm{mM}$ Tris $-\mathrm{HCl} / 0.1 \mathrm{M} \mathrm{NaCl}, \mathrm{pH} 8.0$, at $4^{\circ} \mathrm{C}$ overnight, and an aliquot $(200 \mu \mathrm{g}$ in $200 \mu \mathrm{l})$ of each fraction was added to $5 \mu \mathrm{HLS}$ and $10 \mathrm{mM} \mathrm{CaCl} \mathrm{Cl}_{2}$ [19]. After incubation for $1 \mathrm{~h}$ at room temperature, the test tube was tilted to test whether the solution was transformed into a gel state.

\subsection{Matrix-assisted laser desorption/ionization- time-of-flight (MALDI-TOF) mass spectrometry}

The clottable protein was dialyzed against distilled water and adjusted to a concentration of $0.4 \mu \mathrm{g} \mu 1^{-1}$. An equal volume of sinapinic acid was added to the sample and $1 \mu 1$ of this solution was deposited onto the tip of the probes and crystallized under vacuum. The molecular mass of the protein was determined by MALDI-TOF mass spectrometry (Model G2025, Hewlett-Packard, USA).

\subsection{Amino acid composition and sequence}

Amino acid composition was analyzed after the vapor-phase hydrolysis of the sample at $158^{\circ} \mathrm{C}$ for $30 \mathrm{~min}$ using $7 \mathrm{M} \mathrm{HCl} / 10 \% \mathrm{TFA} / 0.1 \%$ phenol [3], and the hydrolysate was derivatized to dimethylaminoazobenzenesulfonyl amino acids before separation by reversedphase HPLC [20]. The hydrolysate of hen egg white lysozyme was used as a reference for the composition analyses. The N-terminal amino acid sequences of the clottable proteins were determined with a gas-phase sequencer coupled with an on-line HPLC system (Model 477A, Applied Biosystems, USA).

\subsection{Monosaccharide analysis}

The lyophilized clottable protein $(50 \mu \mathrm{g})$ was dissolved in $100 \mu 1$ of water. The sample was mixed separately with an equal volume of $4 \mathrm{M}$ trifluoroacetic acid and with two volumes of $4 \mathrm{M} \mathrm{HCl}$ before being hydrolyzed at $100^{\circ} \mathrm{C}$ for $6 \mathrm{~h}$. The hydrolysate was dried in a vacuum by centrifugation, and then analyzed by a anion-exchange chromatography system (Dionex, USA). The quantity of sugar peaks were analyzed with a pulsed amperametric detector and sugar standards were used for calibration of these peaks [15].

\subsection{Antiserum}

The clottable protein band $(190 \mathrm{kDa})$ in $5 \%$ gel after conducting the SDS-PAGE was stained and cut-out for elution. The eluted and lyophilized protein was used for an antigen to immunize New Zealand white rabbits by multiple subcutaneous injections. The polyclonal antibodies were induced and harvested according to the method of Harlow and Lane [16].

\subsection{Immunodiffusion}

We have collected the hemolymph from the following decapods: P. monodon, Penaeus japonicus, Metapenaeus ensis, Macrobrachium rosenbergii, Procambarus clarki, Scylla serrata, Charybdis feriatus, and Panulirus versi- 
color. Immunodiffusion was carried out on $1 \%$ agar gel (2 mm thickness) [26]. The antiserum and hemolymph were placed in different wells and the gel was incubated in a humid chamber for $24 \mathrm{~h}$. The precipitation lines were observed after the gel was stained with Coomassie brilliant blue R-250.

\subsection{Immunoblotting}

The purified clottable protein, the hemolymph of $P$. monodon and $P$. japonicus were subjected to a reducing SDS-PAGE (5\% gel) and transferred electrophoretically to a PVDF membrane [30]. The blotted membrane was allowed to react with rabbit anti-clottable protein antibodies, followed by incubation with alkaline phosphatase-conjugated goat anti-rabbit IgG. A color reaction was generated by adding nitro blue tetrazolium and 5-bromo-4-chloro-3-indolyl phosphate (Sigma).

\section{Results}

\subsection{Purification of the clottable protein}

Purification of the clottable protein from tiger shrimp was achieved by two sequential chromatography on a TSK DEAE-650 column (Fig. 1). The apparent molecular weight and purity of the eluted proteins were analyzed by SDS-PAGE with a $2.5-7.5 \%$ gel gradient [25] (Fig. 2). It appeared that fractions 26-34 of peak I contained mainly hemocyanin, fractions 35-69 of peak I contained hemocyanin and the dimeric clottable protein (Fig. 1A). Peaks II and III were found to contain aggregated form of the clottable proteins as revealed by SDS-PAGE (data not shown), and the yield of peaks II and III were 21.4 and $13.6 \mathrm{mg}$ from 30 $\mathrm{ml}$ plasma, respectively (Fig. 1A). Fractions 35-69 of peak I $(32 \mathrm{mg})$ were pooled and dialyzed with TE buffer containing $0.1 \mathrm{M} \mathrm{NaCl}$, then re-chromatographed on a DEAE-650 column equilibrated with the same buffer. Hemocyanin was eluted by $0.21 \mathrm{M}$ $\mathrm{NaCl}$ in TE, the clottable protein $(13.9 \mathrm{mg})$ was eluted by $0.24 \mathrm{M} \mathrm{NaCl}$ in TE, and aggregated form of the clottable protein $(2.4 \mathrm{mg})$ was eluted by $0.3 \mathrm{M} \mathrm{NaCl}$ in TE (Fig. 1B). Clottable proteins were also purified from $P$. japonicus [4] and M. rosenbergii (Fig. 3) by procedures similar to those described above.

\subsection{Molecular weight determination}

The purified clottable protein from $P$. monodon migrated as a single band of $190 \mathrm{kDa}$ in SDS-PAGE gel under reducing conditions, and as a band of $380 \mathrm{kDa}$ under non-reducing conditions (Fig. 2). Thus, the protein exists as a homodimer linked by disulfide bonds. A minor band (with a subunit of $180 \mathrm{kDa}$, presumably a degraded form of the clottable protein) was sometimes observed (Fig. 2). Moreover, the molecular mass of the clottable protein was confirmed to be $380750 \pm 800$ by MALDI-TOF mass spectrometry (Fig. 4).

\subsection{Oligomerization of clottable protein by hemocyte lysate}

To follow the time course of the clotting, $1 \mu 1$ HLS was added to a microfuge tube containing $10 \mu \mathrm{g}$ purified clottable protein in $30 \mu 1$ of $50 \mathrm{mM}$ Tris $-\mathrm{HCl}$ buffer containing $0.1 \mathrm{M} \mathrm{NaCl}(\mathrm{pH} 8.0)$, reaction was started by the addition of $1 \mu 10.3 \mathrm{M} \mathrm{CaCl}_{2}$. The reaction was stopped at various time intervals by adding $8 \mu 1$ sample buffer $(60 \mathrm{mM}$ Tris $-\mathrm{HCl}, \mathrm{pH} 6.8$, $2 \%$ SDS, $25 \%$ glycerol, $14.4 \mathrm{mM}$ 2-mercaptoethanol, $0.1 \%$ bromophenol blue) and heated immediately at $95^{\circ} \mathrm{C}$ for $5 \mathrm{~min}$. The samples were subjected to SDSPAGE under reducing condition on a $2.5-7.5 \%$ gradient gel. The higher oligomeric forms increased rapidly with incubation time, while the band of the $190 \mathrm{kDa}$ subunit decreased concomitantly. For example, the 380-
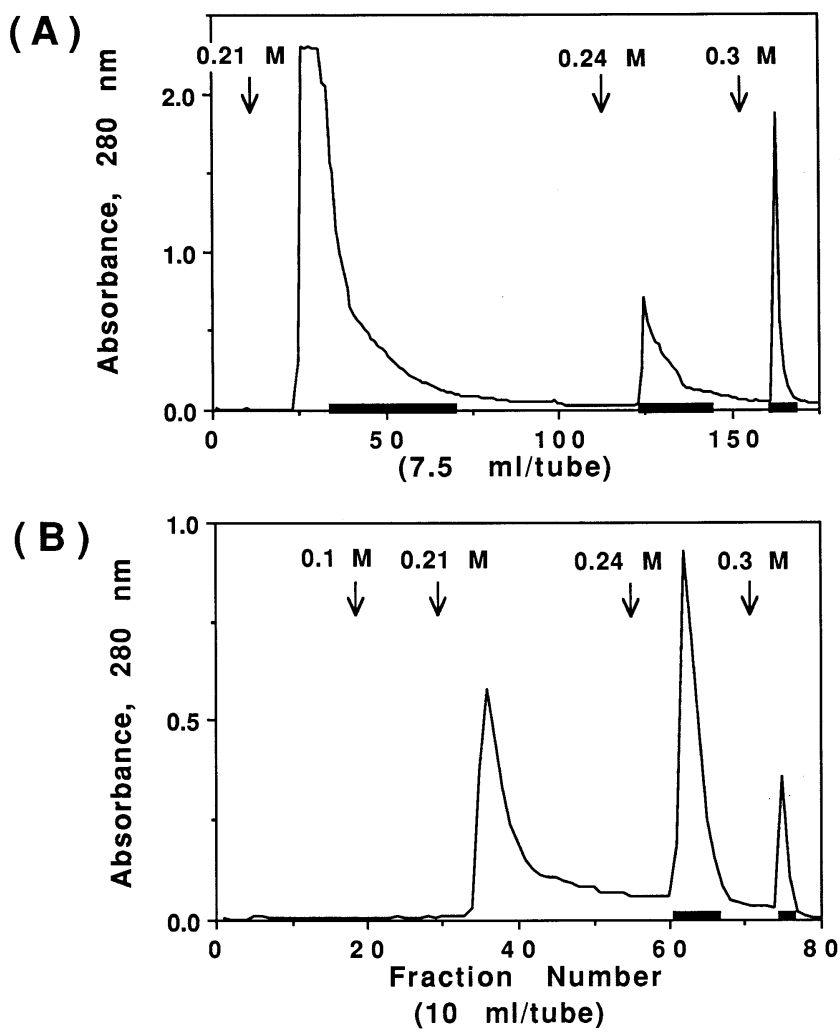

Fig. 1. Purification of the clottable protein from P. monodon. (A) First DEAE anion-exchange chromatography. The plasma $(30 \mathrm{ml})$ was loaded onto a column equilibrated with Tris-EDTA buffer, and subsequently eluted with $0.21,0.24$ and $0.3 \mathrm{M} \mathrm{NaCl}-\mathrm{TE}$ buffer. (B) Second chromatography of fractions 35-69 from (A) using the DEAE column equilibrated with the buffer plus $0.1 \mathrm{M} \mathrm{NaCl}$. The bars denote fractions capable of clotting. 


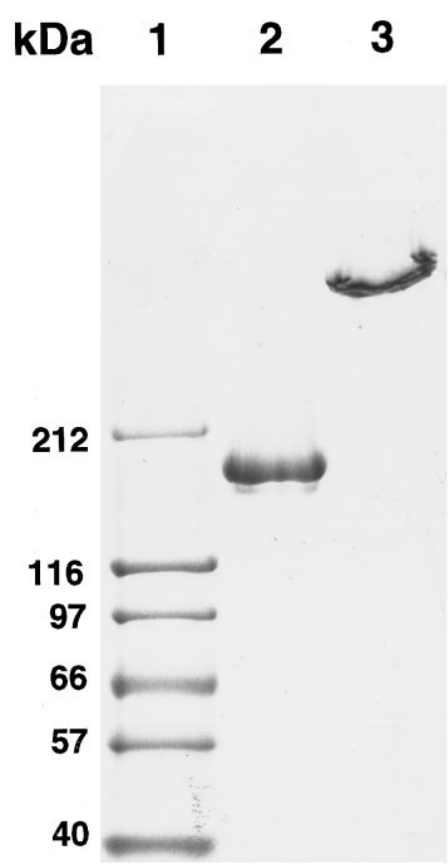

Fig. 2. SDS-PAGE of the purified clottable protein. Lane 1, molecular mass marker; lane 2, reduced clottable protein; lane 3, non-reduced clottable protein.

$\mathrm{kDa}$ dimers were detectable within $30 \mathrm{~s}$ after addition of the HLS, larger polymers were detected in $5 \mathrm{~min}$, and the clot became too large to enter the gel after 15 min (Fig. 5). After $15 \mathrm{~min}$ the minor band of the $360-\mathrm{kDa}$ protein was also shifted to larger forms which could not enter the gel (Fig. 5, lane 5). In control experiments where EDTA instead of $\mathrm{Ca}^{2+}$ was added, there was no polymerization of the clottable protein (data not shown).

The cross-reactivities between the tiger shrimp HLS and the clottable proteins from other species including several penaeid shrimps and $M$. rosenbergii were confirmed by conducting gel-shifting test similar to that of Fig. 5 (data not shown).

\subsection{Amino acid composition and sequence}

Amino acid composition of the purified tiger shrimp clottable protein and those of the homologous proteins from lobster [11] and crayfish [21] are listed in Table 1. These proteins have similar amino acid compositions. The N-terminal amino acid sequence of the shrimp protein up to the 30th residue was determined by automated sequencing. It is shown in Table 2 that the $P$. monodon sequence is about $60-80 \%$ identical to those of the clottable proteins of the shrimp $P$. japonicus, the lobster $P$. interruptus [8], the crayfish ( $P$. leniusculus) [14], and the freshwater prawn ( $M$. rosenbergii ).

\subsection{Glycan analysis}

Positive results of the PAS staining [22] of the $P$. monodon clottable protein on SDS-PAGE suggests that it contains sugar. The monosaccharide content of the protein was determined after acid hydrolysis by anion-exchange chromatography [15]. The clottable protein contains $0-1.4 \%$ glucose, $2.6 \%$ mannose and $1.2 \%$ glucosamine (presumably from $N$-acetylglucosamine). The protein probably contains $N$-glycan of high mannose type, as commonly found in invertebrate glycoproteins.

\subsection{Lipid staining}

We used the staining method of Oil Red O [24] after SDS-PAGE of the clottable protein to check whether it contains lipid or not. The results were negative even after up to $80 \mu \mathrm{g}$ of the purified protein were loaded on the gel (data not shown).

\subsection{UV spectra and thermal stability}

The clottable protein was dialyzed against $50 \mathrm{mM}$ Tris, $\mathrm{pH} 8.0$, and adjusted to $0.3 \mathrm{mg} \mathrm{ml}^{-1}$. UV spectra of the protein were obtained by scanning on a UV-Vis spectrophotometer (Hitachi, Model U 3200, Japan) at least twice. The thermostability of the protein was studied by incubating the sample for 5 min at temperatures between 25 and $55^{\circ} \mathrm{C}$ with an increment of $5^{\circ} \mathrm{C}$ and between 58 and $76^{\circ} \mathrm{C}$ with an increment of $2^{\circ} \mathrm{C}$, then cooled down to $25^{\circ} \mathrm{C}$ for UV absorption spectrophotometry. The protein had an absorbance maximum at $279.5 \mathrm{~nm}$ at $25^{\circ} \mathrm{C}$ as a typical tryptophan-containing protein. The protein appears to be stable at temperatures below $66^{\circ} \mathrm{C}$, and the UV spectra was almost identical to that at $25^{\circ} \mathrm{C}$. However, the protein precipitated out at $76^{\circ} \mathrm{C}$ and above.

\subsection{Immunodiffusion and immunoblotting}

The hemolymph was collected from eight local common crustacean species (see Section 2). The antibodies against the clottable protein were shown to react with the hemolymph of $P$. monodon and $P$. japonicus, but not those decapods of different genera (Fig. 6A). Both the hemolymphs of $P$. monodon and $P$. japonicus were subjected to Western blot analysis. A single band of the $P$. japonicus protein on the membrane reacted with the antibodies (Fig. 6B, lane 3 ), as did the cross-linked form of the clottable protein (Fig. 6B, lane 2). 


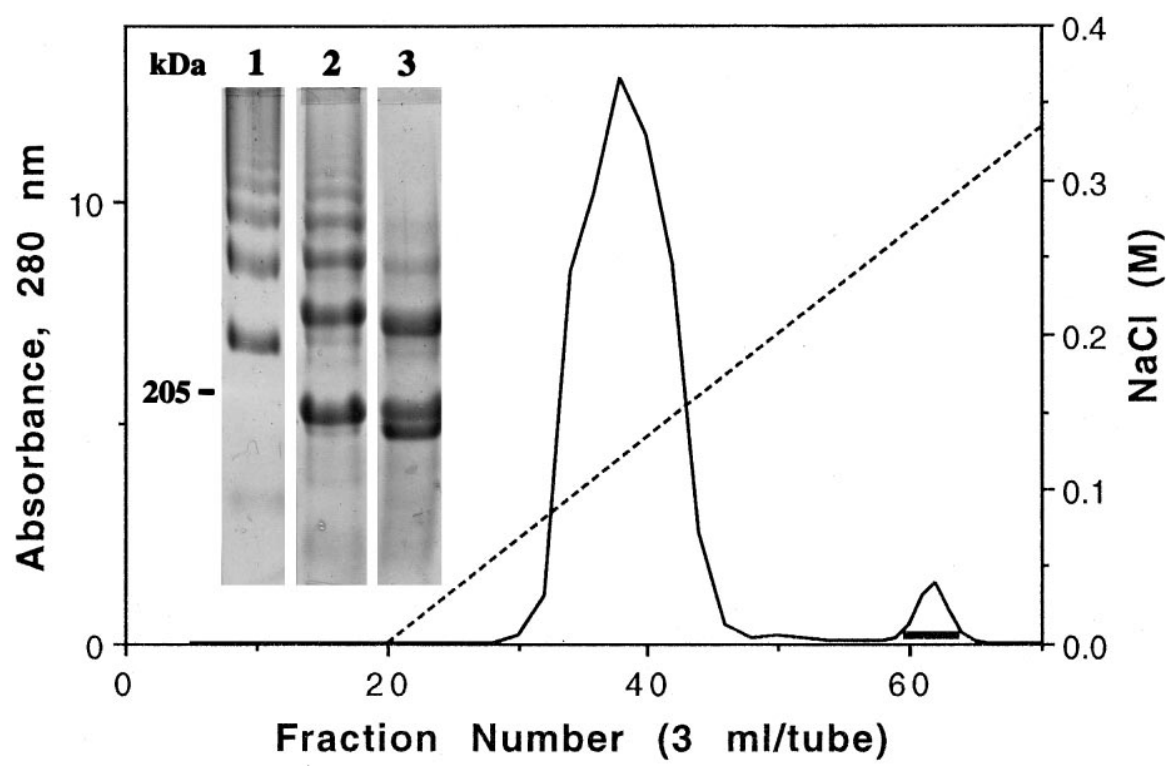

Fig. 3. Purification of the clottable protein from M. rosenbergii on a TSK DEAE-650(S) column. From 2 ml of the hemolymph loaded, 12 mg of the clottable protein were purified (second peak). The first peak contained hemocyanin. Inset: SDS-agarose gel (2.5\%) showing the molecular mass of the clottable protein of: lane 1, M. rosenbergii (non-reduced); lane 2, M. rosenbergii (reduced); lane 3, P. monodon (reduced). Molecular masses of the markers are shown on the left.

\section{Discussion}

We were able to purify the hemolymph clottable protein from $P$. monodon successfully by repeated sequential chromatography on a TSK DEAE-650 column. The results of a linear gradient of $\mathrm{NaCl}$ were not as good as the step-wise elution for purification of the clottable protein. With their lysine $\epsilon$-amino groups modified in the cross-linking reaction, polymerized clottable proteins became more acidic than the dimeric protein and were eluted from the anion exchanger with a higher concentration of salt (Fig. 1A). Previously, lobster clottable protein was purified by isoelectric precipitation at $\mathrm{pH} 5.0$ followed by gel filtration [11]. In analogy, the clottable protein of crayfish was isolated by repeated precipitation in $10 \mathrm{mM}$ phosphate buffer, pH 6.0 [21]. We also have tried to isolate tiger shrimp clottable protein by precipitation in phosphate buffer ( $\mathrm{pH} 5.0$ or 6.0 ), but the yield and purity were not satisfactory.

The molecular mass of the clottable protein of $P$. monodon is estimated to be $380 \mathrm{kDa}$ (Fig. 4), which is slightly smaller than those reported for the proteins from spiny lobster [10] and crayfish [21]. However, their amino acid composition and $\mathrm{N}$-terminal sequences are similar (Tables 1 and 2), suggesting they are homologous proteins. The shrimp clottable protein is able to form stable clots in the presence of $\mathrm{Ca}^{2+}$ and the HLS which contains $\mathrm{Ca}^{2+}$-dependent transglutaminase activities (Fig. 5). Similar coagulation systems and hemolymph clottable proteins appear to be present in lobster [12], fresh water prawn (Fig. 3) and crayfish
[21]. In contrast, the coagulogen and amebocyte of horseshoe crab [18] bear no structural and mechanistic similarities to the crustacean coagulation system.

The shrimp clottable protein was thermostable up to $66^{\circ} \mathrm{C}$. However, proteolysis at the C-terminal region of the protein probably occurred during its collection and purification since we found that the $360-\mathrm{kDa}$ minor form has an identical $\mathrm{N}$-terminal sequence to that of the $380-\mathrm{kDa}$ form. Similar type of degradation was previously reported for the purification of lobster fibrinogen [7] and crayfish clotting protein [21]. By immunoblotting of the crude hemolymph after reduced gel electrophoresis, we detected both forms of the 190and $180-\mathrm{kDa}$ subunits from the stored, but only the $190-\mathrm{kDa}$ subunits from freshly prepared hemolymph. Moreover, there were relatively higher contents of the degraded form when the clottable protein was purified from the hemolymph stored at $-18^{\circ} \mathrm{C}$ for 2 years (data not shown). Since both forms are capable of clotting (Fig. 5), proteolytic activation appears not to play such an important role in the shrimp clotting system as in the horseshoe crab system [18].

The clottable proteins from the spiny lobster $[11,12]$ and the crayfish [21] have been reported to be lipoglycoproteins and suggested to be involved in lipid transport [14]. However, negative results were obtained for the shrimp clottable protein even when large amounts were loaded on the gel and subjected to staining with Oil Red O. Thus, the lipid content of the shrimp protein may be under the detection limit or the lipid moiety was dissociated from the protein in the presence of SDS during the electrophoresis. 


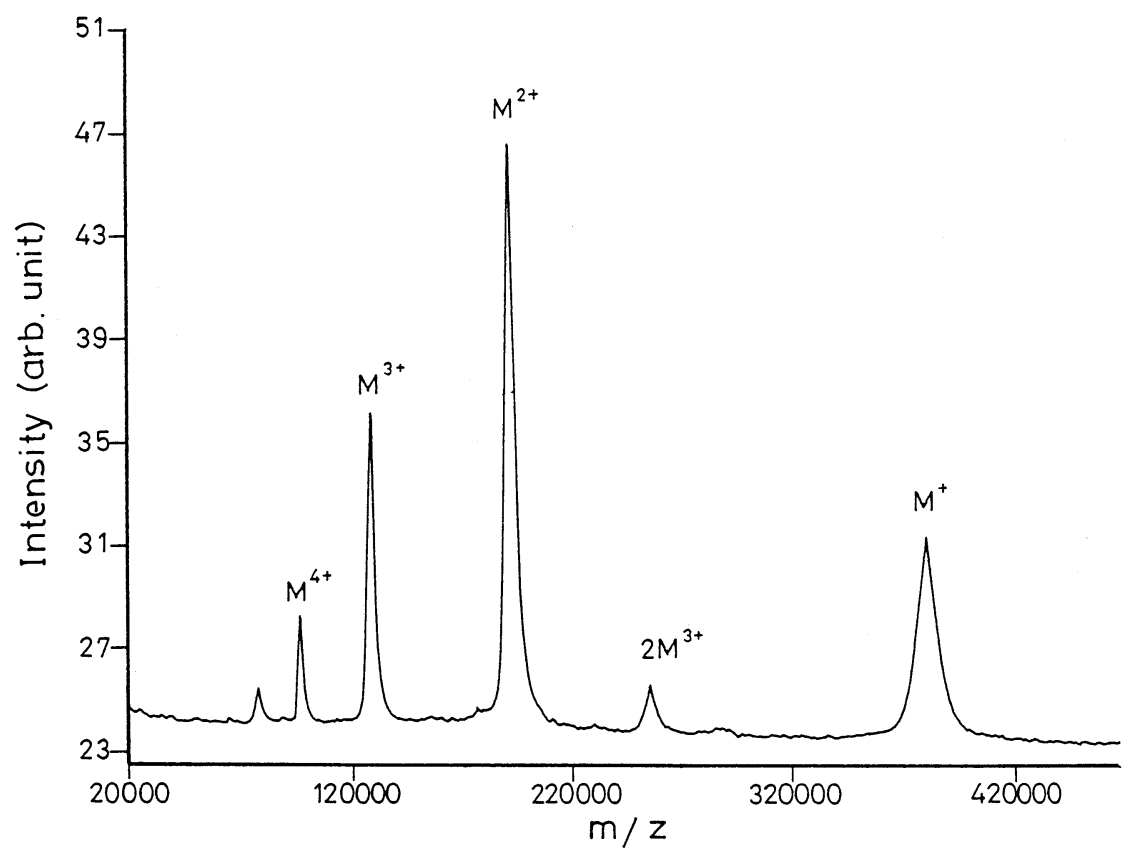

Fig. 4. MALDI-TOF MS analysis. Positive-ion MALDI-TOF mass spectrum of the clottable protein is shown. The relative molecular mass of $\mathrm{M}^{+}$is $380750 \pm 800$.

Notably, the hemolymph of $P$. japonicus and $P$. monodon reacted with the anti-clottable protein antibodies (Fig. 6A). The precipitation line with a spur indicates that the $P$. japonicus clottable protein is structurally very similar to that of $P$. monodon but contain epitopes not identical with that of the $P$. monodon protein. The subunit molecular mass of the $P$. japonicus protein is slightly larger than that of the $P$. monodon protein (Fig. 6B). Apparently, the clottable proteins of lobsters, crabs, and freshwater prawns are immuno-

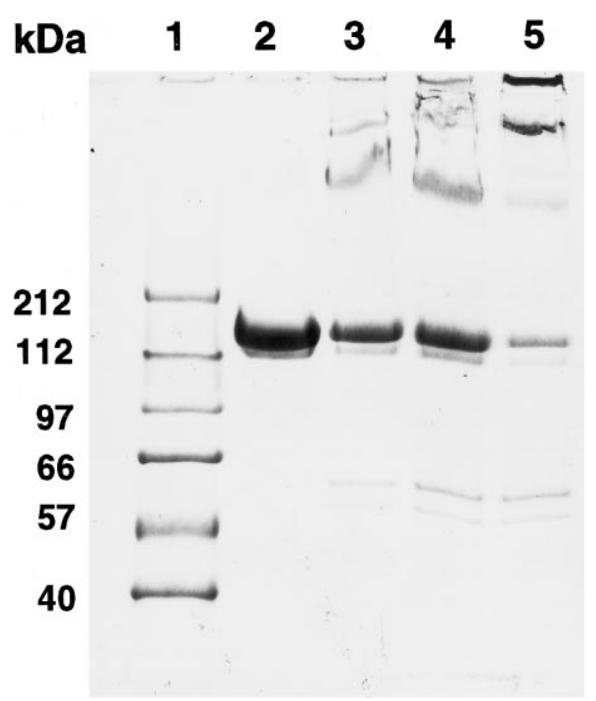

Fig. 5. Polymerization of $P$. monodon clottable proteins after adding the HLS and $\mathrm{Ca}^{2+}$. Lane 1, molecular mass marker; lane 2, the clottable protein only; lanes $3-5$, the protein incubated with HLS and $\mathrm{Ca}^{2+}$ for $30 \mathrm{~s}$, and 5 or $15 \mathrm{~min}$, respectively. chemically distinct from the penaeid clottable protein. Similar high-molecular weight clottable proteins appear to be present in the hemolymphs of most of the decapods and may be responsible for coagulation and haemostasis of the animals $[4,8,21]$ (Fig. 3). The structural similarities between the clottable proteins of $P$. monodon and those of lobster and crayfish are probably not very high (Table 2), therefore there were no im-

Table 1

Amino acid composition of clottable proteins isolated from tiger shrimp (this study), lobster ( $P$. interruptus) [11] and crayfish $(P$. leniusculus) [21]

\begin{tabular}{|c|c|c|c|}
\hline \multirow[t]{2}{*}{ Amino acid } & \multicolumn{3}{|c|}{$\%$ Composition $(\mathrm{m} / \mathrm{m})$} \\
\hline & Tiger shrimp & Lobster & Crayfish \\
\hline Asx & 9.2 & 9.9 & 9.1 \\
\hline Thr & 6.3 & 7.1 & 8.7 \\
\hline Ser & 7.7 & 8.2 & 7.7 \\
\hline Glx & 11.8 & 10.9 & 12.3 \\
\hline Pro & 5.8 & 5.3 & 5.0 \\
\hline Gly & 5.6 & 6.7 & 5.8 \\
\hline Ala & 7.5 & 5.5 & 5.7 \\
\hline Cys & 1.2 & 1.3 & 1.5 \\
\hline Val & 6.9 & 6.9 & 6.5 \\
\hline Met & 1.9 & 1.5 & 1.7 \\
\hline Ile & 5.9 & 5.1 & 6.3 \\
\hline Leu & 7.9 & 9.6 & 8.3 \\
\hline Tyr & 4.2 & 3.2 & 3.1 \\
\hline Phe & 5.1 & 4.1 & 5.2 \\
\hline His & 4.2 & 4.2 & 3.2 \\
\hline Lys & 4.8 & 4.2 & 6.3 \\
\hline Arg & 4.2 & 4.8 & 3.8 \\
\hline
\end{tabular}


(A)

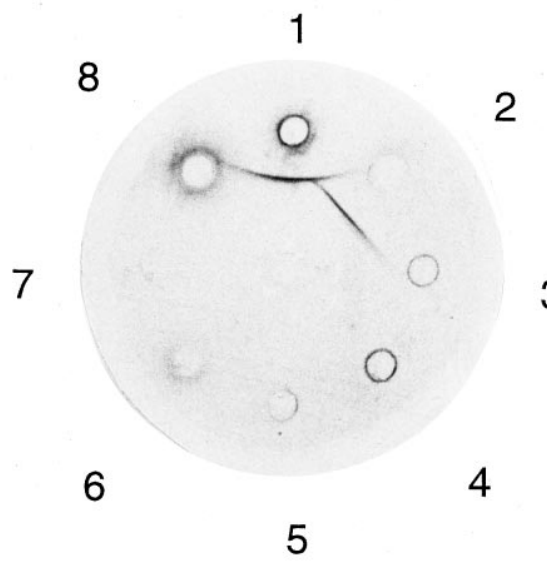

(B)

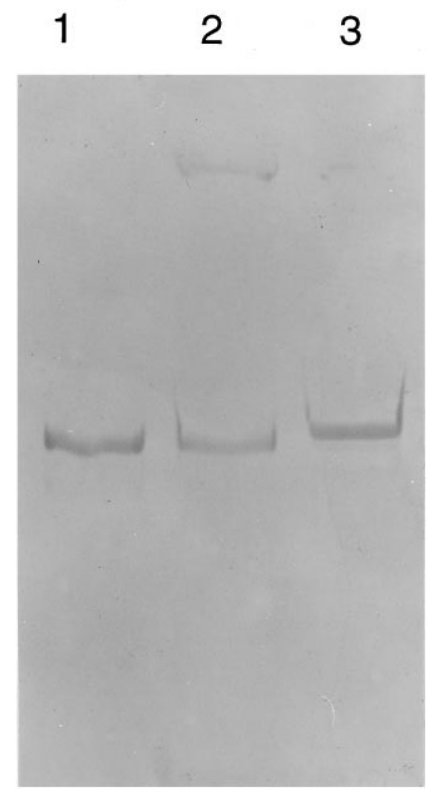

Fig. 6. (A) Immunodiffusion. Center well, anticlottable protein antibodies. Wells 1-8 contained fresh hemolymph of: (1) P. monodon; (2) P. japonicus; (3) M. ensis; (4) M. rosenbergii; (5) P. clarki; (6) S. serrata; (7) Portuna sanguinolentus; and (8) P. versicolor. (B) Western blot analyses. Lane 1, purified clottable protein; lane 2, hemolymph of $P$. monodon; and lane 3 , hemolymph of $P$. japonicus.

munochemical cross-reactivities between their clottable proteins (Fig. 6).

We found previously that the concentration of penaeid shrimp clottable protein was higher in summer than in winter, and was varied by the molting cycle: its plasma levels increased by 2 -fold before molting and decreased after molting to the normal level [4]. However, sex difference in the clottable protein level was not apparent. The concentration level and extent of oligomerization of the protein in the hemolymph also varied between different species (Figs. 1-3). For example, $P$. japonicus clottable proteins tend to form more
Table 2

Comparison of the N-terminal amino acid sequences of the clottable proteins from five decapods

\begin{tabular}{ll}
\hline & Sequence \\
\hline P. monodon & LQPGLEYQYRYSARVASGIPSINRQ- \\
& FALXD \\
P. japonicus & LQPGLEYQYDYDAXV \\
$P$. interruptus & LQPKLEYQYKYHGIVALGIPSYKTQFY- \\
& DAH \\
$P$. leniusculus & LHSNLEYQYRYSGRVASGIP \\
$M$. rosenbergii & LQPGLQXHYRYXXXXXTGIM
\end{tabular}

One-letter codes of amono acids were used; $\mathrm{X}$ denotes those not being confirmed. References for the sequence are: P. interruptus [8]; $P$. leniusculus [14]; the other sequences, this study.

oligomers or polymers and clot faster than the $P$. monodon protein during hemolymph withdrawal.

The N-terminal amino acid sequences of the crustacean clottable proteins show slight similarity to that of the C. elegans vitellogenin [8] which also bears sequence similarity to the vertebrate von Willebrand factor. These plasma proteins are all homodimers of about $400 \mathrm{kDa}$, and may exist as oligomers in plasma $[1,27]$. More sequence information on the crustacean clotting protein is needed to confirm possible evolutionary relationship between these plasma proteins.

\section{Acknowledgements}

The first and the second authors contributed equally to this report. We thank Hong-Nong Chou and JiumMing Jeng for MALDI-TOF mass analysis, C.S. Liu for analyzing sugar composition, Kuan-Fu Liu and Wen-Turn Cheng for the help in collecting hemolymph and Geen-Dong Chang for critical reading of the manuscript. Some material herein forms part of the dissertation submitted by Maw-Sheng Yeh in partial fulfillment for the requirement of Ph.D. degree at National Taiwan University.

\section{References}

[1] Baker ME. Invertebrate vitellogenin is homologous to human von Willebrand factor. Biochem J 1988;256:1059-63.

[2] Bradford MM. A rapid and sensitive method for the quantitation of microgram quantities of proteins utilizing the principle of protein-dye binding. Anal Biochem 1976;72:248-54.

[3] Chang CS, Liu CS. A picomole-level amino acid analysis by means of gas-phase hydrolysis and DABS-Cl/HPLC method. J Chin Biochem Soc 1988;17:12-7.

[4] Chen YL, Huang SH, Cheng JH, Tsai IH. Relationship between hemolymph coagulation and disease in shrimps: (II) Purification and characterization of the hemolymph coagulogen of penaeids (COA Fisheries Series, No. 40, Taipei, ROC). Fish Disease Res 1993;13:1-9. 
[5] Chidalia W, Vendrely R, Montmory C, Coiraut Y, Brouard MO. Coagulation in decapod crustacea. Comparative studies of the clotting process in species from group A, B and C. J Comp Physiol 1981;142:473-8.

[6] Cho PW. The normal morphology and the reaction in inflammatory tissue of hemocytes of grass shrimp (Penaeus monodon). Master thesis, National Taiwan University, Taiwan, ROC, 1988.

[7] Doolittle RF, Fuller GM. Sodium dodycyl sulfate-polyacryamide gel electrophoresis studies on lobster fibrinogen and fibrin. Biochim Biophys Acta 1972;263:805-9.

[8] Doolittle RF, Rily M. The amino-terminal sequence of lobster fibrinogen reveals common ancestry with vitellogenins. Biochem Biophys Res Commun 1990;167:16-9.

[9] Durliat M. Clotting processes in crustacea decapod. Biol Rev 1985;60:473-98.

[10] Durliat M, Vranckx R. Action of various anticoagulants on hemolymphs of lobster and spiny lobsters. Biol Bull 1981;160:55-68.

[11] Fuller GM, Doolittle RF. Studies of invertebrate fibrinogen. I. Purification and characterization of fibrinogen from the spiny lobster. Biochemistry 1971;10:1305-11.

[12] Fuller GM, Doolittle RF. Studies of invertebrate fibrinogen. II. Transformation of lobster fibrinogen into fibrin. Biochemistry 1971;10:1311-5

[13] Greenberg CC, Brickbichler PJ, Rice YH. Transglutaminase: multifunctional cross-linking enzymes that stabilized tissues. FASEB J 1991;5:3071-7.

[14] Hall M, van Heusden MC, Soderhall K. Identification of the major lipoproteins in crayfish hemolymph as proteins involved in immune recognition and clotting. Biochem Biophys Res Commun 1995;216:939-46.

[15] Hardy MR, Townsend RR, Lee YC. Monosaccaride analysis of glycoconjugates by anion exchange chromatography with pulsed amperometric detection. Anal Biochem 1988;170:54-60.

[16] Harlow E, Lane D. Antibodies-A Laboratory Manual. New York: Cold Spring Harbor Lab., 1988.

[17] Hose JE, Martin GG, Gerard AS. A decapod classification scheme integrating morphology, cytochemistry and function. Biol Bull 1990;178:33-45.
[18] Iwanaga S, Miyata T, Tokunaga F, Muta T. Molecular mechanism of hemolymph clotting system in Limulus. Thromb Res 1992;68:1-32.

[19] Kao L-R. Studies on shrimp (Penaeus monodon) hemolymph clotting system and its transglutaminase. Master thesis, National Taiwan University, Taiwan, ROC, 1987.

[20] Kencht K, Chang J-Y. Liquid chromatographic determination of amino acids after gas-phase hydrolysis and derivatization with dimethylaminoazobezene-sulfonyl chloride. Anal Chem 1986;58:2375-9.

[21] Kopacek P, Hall M, Soderhall K. Characterization of a clotting protein, isolation from plasma of the freshwater crayfish Pacifastacus leniusculus. Eur J Biochem 1993;213:591-7.

[22] Leach BS, Colawn JF Jr., Fish WW. Behavior of glycopolypeptides with empirical molecular weight estimation methods. 1. In sodium dodecyl sulfate. Biochemistry 1980;19:5734-41.

[23] Lorand L, Conrad SM. Transglutaminases. Mol Biochem 1984;58:9-35.

[24] Mackness IM, Durrington NP. Lipoprotein separation and analysis for clinical studies. In: Converse CA, Skinner ER, editors. Lipoprotein Analysis-A Practical Approach. UK: IRL Press, 1992:16.

[25] Neville DM Jr. Molecular weight determination of protein dodecyl sulfate complexes by gel electrophoresis in a discontinuous buffer system. J Biol Chem 1971;246:6328-34.

[26] Ouchterlony O, Nilsson LA. Immunodiffusion and immunoelectrophoresis. In: Weir DM, editor. Handbook of Experimental Immunology, 3rd ed, ch 19. Oxford: Blackwell, 1978.

[27] Sadler JE. von Willebrand factor. J Biol Chem 1991;266:2277780.

[28] Stewart JE, Dingle JR, Odense PH. Constituents of the hemolymph of the lobster Homarus americanus. Can J Biochem 1966;44:1447-59.

[29] Tait J. Types of crustacean blood coagulation. J Mar Biol Assoc UK 1911;9:191-8.

[30] Towbin H, Staehelin T, Gordon J. Electrophoretic transfer of proteins from polyacryamide gels to nitrocellulose sheets: procedure and some application. Proc Natl Acad Sci USA 1979;76:4350-4. 